\title{
A Model for Reference: On the Masculinity in The Dahomean ${ }^{*}$
}

\author{
SUI Hong-sheng \\ Zhejiang University, Hangzhou, China
}

\begin{abstract}
This paper is about the model of masculinity exhibited in the African American novelist Frank Yerby's historical novel The Dahomean (1971) which is a classic text for masculinity study but has been ignored. In a flash-back narration, the novel tells us the legendary experience of Nyasanu in Africa before he becomes a slave in the south of America, portrays a well-rounded and authentic Black male character, and constructs a model of masculinity of great value for reference. The model of masculinity demonstrated by Nyasanu is no longer limited by the rigid and unitary stipulations of traditional gender concept. It is a model which integrates tenderness into toughness, combines physical power or military prowess with mental power or wisdom, and most importantly, a model that stresses men's agency and authenticity. At the same time, by the resentment of war and cherishement of life, this model of masculinity exhibits considerable ethical dimension and humanitarianism. It can be said that the model of masculinity inscribed in The Dahomean is of much enlightening importance for contemporary people to reflect upon the patriarchal culture and prevalent gender notions such as gender role concept. As for people's pursueing and constructing their ideal masculinity, the model of masculinity embodied in The Dahomean can be an important model for reference.
\end{abstract}

Keywords: Frank Yerby, The Dahomean, masculinity, authenticity, African American literature

\section{Introduction}

Among the published monographs on the masculinity in contemporary African American novels, Frank Yerby's historical novel The Dahomean (1971) is obviously ignored. As for the study of Black masculinity in African American literature, most publications focus on those novels set in America and about Black males in America, but those set in Africa and about the masculinity of early African males are seriously neglected.

However, the author of this paper firmly believes that the reason this novel is neglected may be where its value lies. The study of the masculinity in such novels as The Dahomean should be an organic and indispensible part of the whole picture. Even though the African Americans have lived in America for about four centuries, yet as peoples of African diaspora, they are still influenced by the early African culture they brought with them to America. If this argument is reasonable, then, the gender concept in early African culture will also influence the cognition, construction, and practice of masculinity of contemporary African Americans. Therefore, the

\footnotetext{
* Acknowledgements: This paper is a result of the project "A Study on the Masculinity in Contemporary African American Literature" (Project No. 12BWW051) supported by the National Social Science Fund of China, and the project "From Unilateral Representation to Multilateral Construction: A Study on the Masculinity in the Novels by Male African American Writers" (Project No. 10YJC752037) supported by Humanity and Social Science Youth Foundation of Ministry of Education of China. SUI Hong-sheng, associate professor, School of International Studies, Zhejiang University.
} 
gender values and certain models of masculinity in early African culture exhibited in such novels as The Dahomean may be a valuable frame of reference.

This paper intends to analyze the model of masculinity exhibited by the hero Nyasanu of The Dahomean. By reading the novel closely and after a detailed analysis of male image of Nyasanu, the author finds that the model of masculinity demonstrated by Nyasanu is much different from those traditional models, either they are "Hegemony", "Subordination", "Complicity", and "Marginalization" models classified by Connell (2005), or the "Genteel Patriarch”, “Heroic Artisan”, and “Self-made Man” models extracted by Kimmel (2006). The model this paper talks about distinguishes itself in four different ways. First, it no longer holds the idea that men should be exclusively tough; on the contrary, it integrates tenderness into it, thus obtaining more humane elements. Second, different from traditional models of masculinity that emphasize the importance of war or violence to their construction and practice, this model shows much resentment to war but deep love to life, thus rewriting the old models in terms of morality and humanitarianism. Third, the traditional models of masculinity emphasize more on the physical power - the wu side, but despise the mental power- the wen side. However, this model encompasses both wen with wu, the mental power with physical power, thus achieving a balance between the two. Fourth, different from the old models which tend to follow the social norms and gender role concepts, this model has a strong sense of authenticity, emphasizing the men's agency in constructinig and practicing their masculinity, thus fulfilling a great turn—from without to within . The following parts will provide a detailed analysis on the four special features of this model.

\section{An Integration of Tenderness Into Toughness}

In The Dahomean, toughness is still the keynote and the main theme of masculinity. Being tough in critical situations is still an principle standard of masculinity. In Nyasanu's personality, courage, stamina, and decisiveness are his consistent characteristics and spiritual virtues for which he never compromises. This can be shown by his performance during the ritual of circumcision. In the novel, before the circumcision starts, he does not need others to fasten him for fear that he will move restlessly during the operation; on the contrary, he askes his fiancee to put a bowl of water on his head, and then says to the operator who performs the operation: "Now, cut me, O knife wielder! And if I spill a single drop from this bowl, you have leave to call me coward” (Yerby, 1971, p. 76). With the flash of the surgeon's knife, a force of blood spouts out. But Nyasanu "sat there like a stature of polished ebony, his head erect, so still the water in the bowl atop his head did not even ripple" (Yerby, 1971, p. 77). This reminds us one main hero GUAN Yu in the Chinese classic novel The Three Kingdoms (2005). In that novel, when GUAN Yu asks the famous doctor HUA Tuo to scrape the poison off the bone, he can even play chess with others. Nyasanu's courageous behavior wins his companions' respect and he is regarded as "the man among men", which establishes a firm foundation for him to be their chief in the near future.

In a battle against a formidable army, Nyasanu does a heroic deed. He captures the prince of Auyo, Subetzy, and forces the enemy's soldiers to put down their weapons and surrender. In this way, he saves his father Gbenu and the king Gezo who are in a critical situation. This magnificent feat typically demonstrates his courage and and wins the respect of the whole Dahomey.

From ancient to modern times, toughness is always the first virtue of masculinity. However, when people try to foster this virtue, they often ignore the emotional factors, neglecting such elements as sympathy, kindness, and compassion in a man's personality and morality. What is worse, to have sympathy and compassion for others will 
be despised as being effeminate. In addition, to attach importance to feeling and to express feeling explicitly is disdained as lack of masculinity. This is clearly exhibited in Kunta Kinte, the hero of Alex Haley's Roots (2007). To maintain his manliness, Kunta always suppresses his feeling and the desire to express any tenderness, thus bringing unnecessary hurts to himself and his mother. In contemporary African American novels, there are many such examples which exhibit African American writers' reflection upon the narrowness, rigidity, prejudice, and inhumanity of traditional models of masculinity.

However, in The Dahomean, the protagonist Nyasanu does not become the victim of such gender concept and social norms. On the one hand, he cherishes feelings and does not fear to express his true feelings. To him, friendship and family love are indispensible factors in his life: "He could not imagine a world without either Kpadunu or his father in it. Such a place would be-a desolation, a wasteland, empty, barren, poor, with no wisdom in it, no help, no comfort, and no joy” (Yerby, 1971, p. 213). On the other hand, he is tough without but tender within, capable of sympathy and compassion. In his father's eye, he is a "young lion with a heart more tender than a maid's” (Yerby, 1971, p. 172). In a skirmish against Maxi, seeing his fellow soldiers cut off the enemy soldiers' head so as to take the credit from the king, Nyasanu could not help vomiting. His such merciful behavior attracts the attention of Kpadunu and Taugbadji who he just rescues. Taugbadji's comment on him also illustrates the tender side of his masculinity: "Thou'lt never make a soldier, Nya! Art tender as a woman, brother” (Yerby, 1971, p. 166). His younger sister Alogba has the same opinion, regarding "big as he is, he's got a woman's heart” (Yerby, 1971, p. 182). However, just as mentioned before, Nyasanu never lacks bravery and fortitude in his character. The reason that he could not kill people in cold blood is not because he is a coward or he does not have the power, but because he could not bear to do that cruel thing.

\section{Resentment of War and Love of Life}

In patriarchal culture discourse, war is the male's sphere to test, prove, and practice masculinity. Some people even believe that long time of peaceful life will make men "effeminate and effete, only by being constantly at war could frontier masculinity be retrieved” (Kimmel, 2006, p. 76). The similar notion is also expressed in Mansfield's Manliness (2006) which maintains that "manliness is best shown in war, the defense of one's country at its most difficult and dangerous" (p. 75). Most times, the heroes of battlefield are always the real men in people's hearts and the heroism they demonstrate can be the synonym of masculinity. Yet when this kind of heroism is abused, it can also be reduced to sort of animality or savagery. The German fascist soldiers' holocaust of Jews and the Massacre committed by Japanese armies and soldiers' in Nanking can be such extreme examples.

In the beginning, just like Henry Fleming, the hero in The Red Badge of Courage (1995), Nyasanu is enchanted by the myth of war upholds certain illusions towards it. Such big words as courage and honor preached by the myth of war still have some alluring power. Therefore, when he is summoned to participate a war after he is newly married, he is excited and full of expectation. He has dreamed for this day for a long time. He dreams "the day on which he, Nyasanu, man among men, his chest adorned with necklaces made of the teeth of the enemies he had slain, strode forwad to offer the huge pile of heads that he, personally hat taken to the king” (Yerby, 1971, p. 135). It is clear that at that moment, he has not thought much about the nature and consequences of the war. Yet under his friend Kpadunu and father Gbenu's guidance, Nyasanu gradually rids of his fascination for war and undertakes a profound understanding of the war's bloodiness, cruelty, and inhumanity. 
In the novel, Kpadunu serves as the first mentor for Nyasanu during the latter's cognition about war. Just before the war against Maxi starts, seeing Nyasanu's craziness about war is almost out of control, Kpadunu intentionally throws cold water on Nyasanu's enthusiasm:

Aye, my brother! I do not like being a member of a race of blood-swilling savages, which is all we children of Da's Belly are, and I wonder if there isn't a place somewhere on the face of earth where people don't kill each other in the name of nonexistent gods or for any reason whatsoever. Where kings rule by love. Where they don't march out to lay siege to and starve and hack to death their brothers... (Yerby, 1971, p. 139)

Obviously, Kpadunu has a thorougher understanding of the essence of war than Nyasanu, and there is a flavor of plain humanitarianism in his discourse. This humanitarianism comes from his cherishment and love of life. In his opinion, the man who kills people coldbloodedly is not a real man or hero, but worse than a beast:

I'll make us men, Nya! You said—ha! — that you must watch that ugly slaughter of bound, gagged, trussed up captives, because it was a thing of men! Is it? I ask you, Brother, is it? No beast of the forest, not even the cruel leopard, kills for pleasure! (Yerby, 1971, p. 140)

From this we can see, in Kpadunu's eyes, bloodthirst should not be "a thing of men", and the power to kill is nothing heroic, therefore not praiseworthy. It is rather a crime. What he says is a kind of epiphany to Nyasanu, making him realize the inhumanity of war and the criminal nature of killing. Therefore, in an encounter battle against Maxi, when he has to shoot a Maxian to save his companion Taugbadji, he does not feel any delight and sense of achievement. On the contrary, he feels that he has committed a serious crime:

The battle drunkenness, blood lust that had invaded him at the sight for his little friends danger drained out of him through his toes. He felt sick; he'd killed a man. He had—-murdered a farmer with a hoe in his hands—from twenty rods away, using a musket. (Yerby, 1971, p. 166)

When he sees his half-sister Alogba—a member of the the king's ahosi-tortures the captives with extreme cruelty and obtains an abnormal pleasure from it, he bursts into rage. Risking being fatally punished by the king, he stops her and beats her with his belt "with all his force” (Yerby, 1971, p. 168). To him, any trampling and insulting of life is unforgivable.

However, although Nyasanu has achieved some perception about the cruelty and inhumanity of war, he still upholds an illusion to war. He just feels it is no honor for his well-equipped army to attack and conquer the poor-armed farmers. He wants to fight the soldiers with the same equipments, as he says to his father:

But what I do know, Tauchi, my father, is that I didn’t march twelve days to murder peasants armed with hoes and working in their fields! I came to face men and warriors, not poor country louts who run like sheep! (Yerby, 1971, p. 171)

That is to say, if the enemy is well-armed, he may not feel any sense fo guilt not matter how many soldiers he kills. It is clear that Nyasanu still has some illusion towards war. His father, who now serves as the second mentor for Nyasanu during the latter's cognition about war, hits the nail on the head by saying:

You expected war to be glorious, my son? It isn't—anymore than life is. I have often thought that nothing degrades a man moren than the nasty stinking business of man killing. We, Vi, are the cruelest beasts who walk earth. No other creatures the vudun have made, no lion, leopard, crocodile, snake, kills except out of hunger or to feed his young. While we kill out of pleasure. Out of blood lust, making the excuse that the gods demand sacrifices of us. (Yerby, 1971, p. 171)

This passage is really a classic disclosure of the ugly essence of war and most profound critique of 
huamn nature. It reveals the falsity and inhumanity of such myths as honor, heroism connected with war, pointing out that it is not a heroic deed to deprive other people's lives, but a sordid business. If human beings can not control their thirst for war, if they take pleasure in killing, they are no better than beasts. This also admonishes those who want to construct and practice their manhood in war that war can only make them lose their humanity and true selves. The reason that Gbenu could obtain such penetrating and profound understanding about war is because his cherishment and love of life that the war constantly threatens to deprive. To him, life is the base of everything.

Under the direction of his friend and father, Nyasanu is totally disillusioned with war, and nurses more cherishment and love of life. Undoubtedly, the resentment of war and love of life adds a dimension of humanitarianism to his masculinity system.

\section{A Combination of Physical Power and Mental Power}

In Chinese gender culture, an ideal model of masculinity is wen wu shuang quan which means "wen and wu are complete in every respect” (Louie, 2002, p. 16). Wen here mainly refers to a man's mental power or wisdom while wu mainly refers to physical power, or "attributes of physical strength and military prowess” (Louie, 2002, p. 14). In other words, this model of masculinity is one that combines physical power and mental power.

Theoretically speaking, the masculinity that encompasses both wen and $w u$ should be one of the ideal models of masculinity for people to follow. Yet, in reality, when talking about masculinity, people tend to emphasize the $w u$ side—physical power, military prowess, or even violence; but easily ignore the importance of the wen side - the mental power, wisdom, or culture. But this is not the case with Nyasanu. During the course of the construction and practice of his masculinity, both wen and wu are developed and a balance is maintained.

Nyasanu's physcial power or his military prowess as a soldier has been fully demonstrated by his heroic deeds in saving his father and the king in a situation of life and death. It is evident that his physical power is never a problem. He is handsome, strong, and the best fighter in his country, the man among men. Yet his wen side, the mental power- the wisdom to deal with people or problems, however, experiences a process of growth in which his best friend Kpadunu plays an important role.

On the one hand, Kpadunu also emphasizes the importance of physical power. This can be demonstrated by his attitude towards the Maxians. Although he feels sympathetic towards them and feels guilty for all the evil things his army has done, he still thinks the Maxians are too weak and lack of necessary military prowess. In his opinion, they have too much servility to fight against their conquerors or enslavers. Yet on the other hand, to people who are unfortunately reduced to slaves, he also regards it as unwise to do anything rash so as to die a meaningless death: "I won't insist that a man should always die first” (Yerby, 1971, p. 173). Here, he emphasizes the importance of the mental power-the wisdom.

At first, Nyasanu does not quite agree with Kpadunu upon this point, thinking that a man can be killed but should not be humiliated and he would rather die than accept the enslavery. For this, Kpadunu points out the stupidity of Nyasanu's mentality while recognizing the nobleness of his thoughts: "But you're very simple, very noble, and very pure-which are nice-sounding ways of saying you're a fool” (Yerby, 1971, p. 173). According to Kpadunu, a man who becomes a slave does not have to die to maintain his integrity. On the contrary, he could get free with wisdom: "If I were ever enslaved, I’d make sure they turned me loose — to live, eat and get fat, love 
women and beget sons” (Yerby, 1971, p. 174). To achieve this purpose, he will play all kinds of tricks to the slave master so that at last he has to set him free.

Under Kpadunu's influence, Nyasanu learns to remain coolheaded and act according to circumstances when dealing with problems. When he is challenged and cornered by the Khetunga, the chief of women soldiers, he acts both courageously and wisely and makes all her efforts go nowhere. When he is asked to go to receive the rewards from king for his heroic deeds, he does not show any rapture or conceitedness, but remains as low-key as possible. He behaves so humbly that during the whole process, he leaves no opportunity for the crafty and fawning officials of the king to frame him.

\section{Agency and Authenticity}

This paper also finds that during the construction and practice of his masculinity, Nyasanu does not blindly follow the prejudiced, unitary, and narrow definitions of masculinity by the gender role concept of patriarchal culture, but looks at his masculinity with an open-minded, multilateral, and humane vision, always keeping a sense of agency and authenticiy in his mind. This can be exhibited from a dialogue between him and his wife Dangbevi:

Stop insulting me by believing me an animal, or a slave to my seed sacks and my dangling gut! I'm a man, Dangbevi; and if you don't know what a man is, what a creature with souls in him, how compounded of dreams, compassion, tenderness, intelligence, pain—and joy—oh yes, and sometimes, rarely, joy! If you don't know that a shaft of moonlight can transfix him, the Otutu's singing stop his breath... (Yerby, 1971, p. 243)

From this passage we can see, the image of a real man in Nyasanu's mind's eye is no longer the rigid and stoic stereotype defined by patriachal culture and its gender role concept, no longer the passive role players in family or society, but a man of emotional and spiritual depth and capable of making his own choice. Unwittingly, he suggests a model of masculinity typically characterized by agency and authenticity.

Here, Nyasanu in no sense "sincerely" conforms the popular model defined by conventions and social norms that men should be "agressive”, "hard”, “assertive”, “cold”, "laconic”, and "stoic” (Mansfield, 2006, p. 23), but "authentically" remains loyal to his true feelings, judgments, and conscience. Most times, when a man constructs or practices his masculinity, he does not resort to his inner self, but "is attuned to catch the signals sent out by the consensus of his fellows and by the instituional agencies of the culture, to the extent that he is scarcely a self at all, but rather, a reiterated impersonation” (Trilling, 1972, p. 66). That is to say, most men do not have much sense of agency or authenticity during the construction and practice of their masculinity. Yet in Nyasanu's system of masculinity, the "self-sufficiency and self-definition" always come first any time he needs to make a judgment or take an action.

When his half-sister sucks the poison out of his body by risking her own life, he does not show any restraint or affectation, but "bent his immense height in half, going down on his knees beore Alogba, pressing his forehead to the ground, and clawing up a handful of earth, poured it over his head” (Yerby, 1971, p. 186). According to the local convention, to put earth over one's own head is a extremely humble way to show one's gratitude. Different from Kunta Kinte who behaves indifferently when he receives his mother's material assistance so as not to be larughed by others, Nyasanu exhibits more agency and authenticity without Kunta's affectation and falsity.

On the battle ground, when Nyasanu knows those captives hit by poisoned arrows will be beheaded, he feels very upset. His companions ridicule him for being too merciful. To this derision, he declares candidly: "I am more woman than man” (Yerby, 1971, p. 167). From this we can see, Nyasanu openly defies against all the 
demarcations between masculinity and femininity. Interestingly, although he does not care much about other people's estimation of his masculinity, he nevertheless wins most respect and recognition, as what his wife says to him when he asks her if he is cruel:

(Y)ou are not cruel. You try to be; but you simply can't be. And it is-your tenderness, Hwesu, that makes you truly a man. You're brave and strong, but so is any of the great beasts. But you're wise and sober and have a kind of quietude in you. A peace. And great tenderness. (Yerby, 1971, p. 406)

This is a classic statement about the truth of masculinity which is quite thought provoking. In the vision of old models of masculinity, Nyasanu is not manly enough since he is not cruel which implies he is not quite capable of violence or playing tough — which we know is not the truth. But by violating the obsolete gender norms and being true to himself, he is a real and authentic man. What his wife says furtherly proves the flexible, multilateral, and authentic nature of the model of masculinity he identifies. This is also a kind of agency that saves Nyasanu from being one of the conformists that most men tend to be. We may darely say, what is argued by Trilling (1972) with a full-length book — the authenticity—is crystalized by Nyasanu, the hero of The Dohomean.

\section{Conclusions}

By the above analysis, we can say that the model of masculinity exhibited by the male figure Nyasanu in The Dahomean transcends the stipulations and restraints imposed by the traditional gender role concept and other social norms. It is a model of masculinity that integrates tenderness into toughness and combines physical power and mental power. At the same time, by the strong resentment against war and deep cherishement of life, this model of masculinity demonstrates a strong dimension of humanitarianism. Philosophically or ethically speaking, this model of masculinity abondons the external, phony, and suppresses properties of traditional models of masculinity, either it is a model of "Hegemony", "Subordination”, “Complicity”, or "Marginalization” classified by power relationships, or the "Genteel Patriarch”, "Heroic Artisan”, or "Self-made Man” defined by the development of history and culture, and emphasizes a man's internal virtues and subjective judgments, thus having much flavor of agency and authenticity.

To conclude, the model of masculinity demonstrated and constructed in The Dahomean is of much enlightening importance for contemporary people throughout the world to reflect upon the patriarchal culture and gender role concept. As for the pursuit and construction of people's proper masculinity, the model of masculinity embodied in The Dahomean can be an important model for reference.

\section{References}

Connell, R. W. (2005). Masculinities. Berkeley: University of California Press.

Crane, S. (1995). The red badge of courage. Ware: Wordsworth Editions Limited.

Haley, A. (2007). Roots. Philadelphia: Vanguard Books.

Kimmel, M. S. (2006). Manhood in America: A cultural history. New York: Oxford University Press.

Louie, K. (2002). Theorising Chinese masculinity: Society and gender in China. Cambridge: Cambridge University Press.

LUO, G. Z. (2005). The three kingdoms. Beijing: Chung Hwa Book Co..

Mansfield, H. C. (2006). Manliness. New Haven: Yale University Press.

Trilling, L. (1972). Sincerity and authenticity. Cambridge: Harvard University Press.

Yerby, F. (1971). The Dahomean. New York: Dell Publishing Co., Inc.. 